\title{
TE CONVIDEI PRO SAMBA E VOCÊ NÃO VEIO
}

ROMULO FRÓES

A música brasileira ainda vive sob a orientação de seus dois movimentos musicais mais importantes que, durante a década de 1960, determinaram um eixo em sua história: Bossa Nova e Tropicália. A primeira redefiniu os parâmetros de nossa canção adensando seu imenso legado e apontando a novíssimas direções; a segunda, excedendo a premissa bossanovista, dilacerou seus limites atingindo quase a não-canção. Em suma, e de maneira bastante reduzida, pode-se dizer que a Bossa Nova representaria os artistas que buscam uma certa sofisticação musical e a Tropicália, aqueles que se identificam com a invenção, ainda que tais características sejam encontradas em ambos os movimentos.

$\mathrm{O}+2$, grupo formado por Domenico Lancelloti, Kassin e Moreno Veloso, transita tanto pela Bossa Nova quanto pela Tropicália, por tudo aquilo que esses dois movimentos agregam ou negam. Não se trata mais de organizar ou destruir um pensamento, há espaço para tudo e para todos em sua música, com idéias apresentadas não mais sob o conteúdo programático de um movimento musical, mas por algo mais íntimo, uma banda. Organizados de modo muito original, ainda que pertençam a uma banda, cada integrante se individualiza a cada CD lançado, estampando na capa seu nome à frente do nome do grupo. Sempre com a colaboração dos demais, todos têm sua vez de "dirigir" o grupo. Desse modo, já lançaram três discos: Moreno+2 Máquina de escrever música (2001), Domenico+2 - Sincerely hot (2003) e Kassin+2 - Futurismo (2006).

A princípio é difícil determinar o que caracteriza a música produzida pelo +2 , dada a quantidade de referências que ela carrega e o modo como se constituem as canções. $\mathrm{Na}$ sua grande maioria elas não se desenvolvem, ficamos esperando por algum desfecho que nunca vem. Quase sempre circulam em uma única parte, e quando 
há uma segunda é mais para se obter variações sonoras (e não harmônicas), sem desdobramentos da melodia, distanciando-se, neste ponto, da Bossa Nova. Em contrapartida, a maneira de cantar dos três compositores segue os passos da Bossa Nova, com uma voz sem corpo, quase anêmica, tendendo ao anonimato - às vezes fica difícil saber quem está cantando. Essa intenção de rebaixamento não se limita à voz, estendendo-se a outros elementos da canção, o que provoca um desfocamento em nossa audição. Há um clima de apaziguamento, esgarçamento, o que leva o ouvinte a dar muitas voltas em torno de uma mesma canção. Mas são justamente dessas voltas que surge a graça da música do +2 , quebrando a monotonia que a princípio parece existir.

A canção, "O seu lugar" (João Donato/Kassin), ilustra bem o que estou tentando dizer. De letra e melodia simples, esta canção é ancorada pelo piano elétrico (Rhodes) de Donato que desfila seu virtuosismo por muito mais variações que sua harmonia pode sugerir. Em um movimento contrário, Kassin inicia a faixa com um som que lembra um metrônomo, como que querendo reforçar sua pulsação ante as improvisações livres do arranjo, mantendo a canção em solo firme. Também a sonoridade sofisticada de Donato é afetada por barulhos que parecem saídos de um filme B de ficção científica. Por fim, é incorporado ao arranjo um telefonema recebido por Donato no momento da gravação: um amigo conta a ele a história de outro amigo em comum que, após beber muita cerveja e seguir viagem, ao ver recusado pelo motorista seu pedido para encostar o ônibus para que ele pudesse aliviar seu aperto, resolve seu problema mijando no corredor do veículo. Essa conversa avacalhada sobre uma situação absurda aparece na canção quando ela se "desgarra" em um longo solo instrumental; ao mesmo tempo a traz de volta, humaniza o gênio de Donato e desfaz um pouco a extrema doçura que a música possui.

A faixa que dá título ao disco de Kassin, "Futurismo" (Domenico e Kassin), apresenta o mesmo movimento. Com participação de Jorge Mautner, a canção é um pequeno manifesto ecológico, um exercício de futurologia sobre o destino da Terra. O retrato é um tanto desanimador, mas é interrompido por um discurso delirante de Mautner sobre neurônios saltitantes, sugerindo que, se manipulados, eles podem salvar o planeta da ameaça do ser humano. A retórica tropicalista de Mautner é abandonada aqui de seu violino estridente e dá lugar a um delicado arranjo de flautas, mas ainda encontra forças para chacoalhar as boas intenções da música.

É interessante notar como nesses encontros, ainda que com muito respeito, há um enfrentamento rico para ambas às partes. Se de um lado o +2 rejuvenesce a música de Donato e Mautner, interfe- 
rindo na sonoridade já muito conhecida dos dois músicos, por outro, estes trazem experiência e uma complexidade maior às composições do grupo. É nesta contraposição que reside muito de sua força, quando o enfrentamento não acontece, o que é pra ser homenagem ganha ares de paródia.

Contudo, a paródia também faz parte do repertório da banda. Mais trabalhado em estúdio, o disco de Domenico, Sincerely hot, é o mais eletrônico e, de certo modo, o mais experimental dos três discos: todo ligado por melodias, sons e texturas extraídos de sintetizadores e programações que passeiam de uma faixa à outra do início ao fim, sem intervalos entre elas. Domenico busca no humor a saída para vencer um certo hermetismo para o qual ele parece derivar. "Não queria você me levando a sério, só queria você me tirando do sério", ele canta logo na faixa de abertura "Alegria, vai lá", composição sua e de Kassin. Esse humor aparece tanto pela ironia, sampleando instruções de meditação de um professor de yoga em "Telepata" (Kassin, Moreno e Domenico) ou exagerando no clichê soul à la Barry White na propositalmente melosa "Felizes ficaremos na estrada" (Kassin e Domenico), como pelo escracho, caso da faixa-título "Sincerely hot" (Domenico). Nesta, porém, o compositor não esconde seu constrangimento ao pronunciar algo que nem parece fazer parte da canção: "eu vou tocar nos seus peitos, eu vou chupar suas mãos, eu vou ranger o seu dente, eu vou comer essas garotas", com um riso nervoso como um garoto que comete uma traquinagem. "Te convidei pro samba e você não veio, você me deixou no samba e eu vou te esquecer mulher", canta Domenico em "Te convidei pro samba" (Pedro Sá, Maurício Pacheco e Domenico), bem diferente de Nelson Cavaquinho em "Vou partir" (Nelson Cavaquinho e Jair Costa): "vou partir, não sei se voltarei, tu não me queiras mal, hoje é carnaval". Não se trata só de se dar bem com as garotas, é preciso estar bem com elas.

Já falei em doçura e boas intenções para me referir às canções do +2 , poderia acrescentar os adjetivos calmo e belo, ou ainda dizer que elas têm certo acento infantil, tudo isso para apontar o que me parece maior no comportamento e na música do grupo: uma delicadeza que se desprende das canções e que se sobrepõe às suas inúmeras camadas de som e de informação musicais.

Por ser o mais despido dos três CDs, fundamentalmente apoiado no violão e na interpretação de Moreno, em Máquina de escrever música essa delicadeza ganha contornos mais claros nos múltiplos caminhos que o disco toma. Resulta, por exemplo, na bela melodia de "Deusa do amor" (Adailton Poesia e Valter Farias) que, antes soterrada pelos poderosos tambores do grupo Olodum, agora ressurge límpida em meio à batida do violão. Em outra regravação, Moreno 
encontra novas nuanças na canção já bastante conhecida, "Esfinge" (Djavan), levada aqui num andamento bem mais lento que o original. Procedimentos bossanovísticos em um disco de comportamentos tropicalistas, Moreno canta e compõe em espanhol em "Para Xó" (Moreno Veloso), balbucia palavras em italiano no quase axé "Arriverdeci" (Moreno Veloso) e, acompanhado pelo piano de Daniel Jobim, canta "I'm wishing" (Morey e Churchill) parte em inglês, parte em português, na versão de Aloísio de Oliveira para o tema de Branca de Neve. Recupera também uma canção do sambista paulista Henricão, a linda "Só vendo que beleza" (Henricão e Rubens Campos) e ainda cita "Essa é pra tocar no rádio", de Gilberto Gil, na canção "Assim" (Moreno Veloso).

Tanto nas regravações como nas composições autorais Moreno mostra o ecletismo característico do +2 , para talvez dar conta do universo que forma a música do grupo, absorvendo e interferindo em suas influências. Se em "Rio longe" (Moreno Veloso) o compositor flerta com o gênero axé, tocando pessoalmente os surdos virados característicos do estilo, em "O livro e o beijo" (Moreno Veloso) mistura os tambores a percussões eletrônicas em busca de uma nova sonoridade pop.

Um ciclo foi cumprido nestes três discos. Se o primeiro é uma espécie de apresentação da música do +2 , de sua origem e suas direções, se tais direções foram desenvolvidas no disco seguinte, de Domenico, o último, de Kassin, define o vocabulário do grupo, um dos mais originais na música popular brasileira contemporânea. Moreno, Domenico e Kassin estão no centro de um novo capítulo da MPB, talvez ainda cedo para ser percebido, mas que já influenciou grande parte do que está sendo produzido hoje. E não influenciou apenas jovens artistas. Caetano Veloso, por exemplo, por intermédio de Moreno e seus amigos, sobretudo o guitarrista Pedro Sá, em seus dois últimos $\mathrm{CDs}$ travou contato com uma sonoridade do rock diferente das que já havia experimentado, o que certamente levou a uma mudança em sua lírica. Apresentar alguma novidade a um artista que pauta sua carreira por isto não é pouca coisa. Eles estão nos convidando pro samba, eu iria se fosse você.

ROMULO FRÓES é cantor e compositor paulistano e tem três discos lançados: Calado (2004), Cão (2006) e No chão semo chão (2009). 